\title{
THE ECONOMIC IMPACT OF HUNTING IN THE LIMPOPO PROVINCE
}

\author{
Peet van der Merwe* \\ North-West University \\ peet.vandermerwe@nwu.ac.za \\ Melville Saayman\# \\ Riaan Rossouw+ \\ North-West University \\ North-West University \\ melville.saayman@nwu.ac.za \\ riaan.rossouw@nwu.ac.za \\ Received: October 2013 \\ Accepted: August 2014
}

\begin{abstract}
This study evaluated the economic impact of hunting on the regional economy of South Africa's Limpopo Province. Data on biltong hunting was derived from a national survey conducted in 2009 and data on trophy hunting from the Professional Hunting Association of South Africa (PHASA). Using the input-output (social accounting matrix) and multiplier analyses, we found that the direct economic impact of hunting in the regional economy of the Limpopo Province, as a result of increased expenditure, exceeded R669 million (US\$83.6 million). This direct impact resulted in a total economic impact in the order of R1.2 billion (US\$150 million) and consequently in a multiplier effect of 1.76 . With regard to employment, we estimated that some 8382 jobs, in addition to those of the employees directly involved, may be dependent upon hunting in the province, which supports the notion that this is a viable and important sector of the tourism industry.
\end{abstract}

\section{Keywords}

Accounting matrix, biltong hunting, economic impact, hunting, South Africa, Limpopo Province, tourism, trophy hunting

\footnotetext{
*Prof P van der Merwe is a professor in at TREદS (Tourism Research in Economic Environs and Society), North-West University, Potchefstroom, South Africa.

\#Prof M Saayman is the Research Director of TREદS (Tourism Research in Economic Environs and Society), North-West University, Potchefstroom, South Africa.

+Prof R Rossouw is a professor in the School of Economics, North-West University, Potchefstroom, South Africa.
} 


\section{INTRODUCTION}

Wildlife-based tourism is attracting increasing interest from governments and the tourism industry alike. Whale watching, safaris, bird watching, fishing, and hunting are among the many activities involved. Higginbottom (2004:2) defines wildlife tourism as "tourism based on encounters with non-domesticated (non-human) animals such as springbok, elephant and lions." It can take place either in the animals' natural environment, such as reserves, game farms, and national parks or in areas where animals are in captivity, such as zoos and wildlife breeding institutions. Wildlife tourism activities can be classified into two main groups: nonconsumptive (e.g., viewing and photographing wild animals) or consumptive (e.g., hunting and fishing). This study focuses on the latter, specifically hunting.

The greater portion of wildlife tourism in South Africa takes place on more than 6000 privately owned farms and game reserves, which constitute $17.9 \%$ of the total land suitable for agriculture in South Africa (Van der Merwe, 2004; Damm, 2005; Samuelson and Stage, 2007). This translates into 14.7 million ha (Van Hoven 2005). Although hunting does not take place on all of these privately owned game farms, it remains the main sources of income for those that do participate in the activity of hunting (Van der Merwe et al., 2004).

A game farm is defined as land that is adequately fenced, containing a variety of species that can be used for hunting, meat production, live game sales, and to provide infra- and suprastructures for eco-tourists (Van der Merwe et al., 2004). In South Africa hunting is mostly of two kinds, biltong and trophy hunting. Van der Merwe et al. (2004) define biltong hunting as a cultural activity where wildlife is hunted by means of a rifle, bow or similar weapon to produce a variety of meat (venison) products, such as biltong and salamis. Biltong is a kind of cured meat that originated from South Africa and is made from different types of meat, such as beef and game meats as well as ostrich fillets. Biltong is made from raw fillets of meat cut into strips (Van der Merwe and Saayman, 2004). It is similar to beef jerky found in the United States: both are spiced and dried meats, but differ in ingredients used, taste and how they are produced. The main difference is that biltong is not as sweet as jerky.

Trophy hunting may be similarly defined as an activity where wildlife is hunted by means of a rifle, bow or similar weapon, primarily for horns (measured according to Rowland Ward and Safari Club International) and skin, which are displayed as trophies (Saayman et al., 2009).

Wildlife tourism is widely considered to be a growth sector that can contribute significantly to the economy of its host country (Higginbottom, 2004). Damm (2004) says worldwide experience suggests that carefully managed conservation-hunting programmes can contribute significantly to successful wildlife conservation. In 2008 the indigenous species hunted for trophy purposes in South Africa accounted for R724.69 million (at time of writing the exchange rate was 1.00 ZAR = 0.124484 US\$) and exotic species for R4.2 million. The daily fees collected from the trophy hunters (mainly foreign, e.g., from the United States, Germany, and Spain) accounted for R244.2 million, giving a total income of R973.2 million generated by trophy hunting in that year (Lindsey et al., 2007). On the other hand biltong hunting (mainly by local South African hunters) generated R5 billion in the 2009 and 2010 season, made up of R2.3 billion for general expenditure (e.g. accommodation, food, and transport) and R2.7 billion for game hunted (Van der Merwe et al., 2011).

Combined trophy and biltong hunting contributed approximately R6 billion to the South African economy for the 2009 and 2010 season. Research conducted by the International Association of 
Fish and Wildlife Agencies in America (IAFWA) indicated that the total multiplier effect of hunting in the United States was US\$67.5 billion in 2002 (IAFWA 2002). Similar research by Baldus and Cauldwell (2004) in Tanzania showed that gross income from hunting was US\$27.6 million in 2001.

These amounts support the belief that hunting has the potential to generate employment opportunities and spread wealth to more rural areas of the country, as most provinces where hunting is conducted are rural, such as the Limpopo Province (Van der Merwe and Saayman, 2008). Most of South Africa's hunting takes place in five of the nine provinces: Free State, Northern Cape, North West, Limpopo, and Eastern Cape (PHASA, 2009; Warren, 2011; Van der Merwe et al., 2011). Of these, the Limpopo Province benefits most from hunting (Van der Merwe et al., 2011; Warren 2011), for three reasons: first because $50 \%$ of all privately owned game farms and conservation areas in South Africa are located here (Eloff, 2002), second because the largest percentage of biltong and trophy hunters hunt here, and third because a high percentage of the most preferred hunting species (kudu, impala, blue wildebeest, and warthog) are found here (PHASA, 2009; Warren, 2011; Van der Merwe et al., 2011). A study of the Northern Cape, one of South Africa's top three hunting destinations (Warren, 2011), found that hunting contributed R774 million to that province's economy (Saayman et al., 2011). The present study was therefore conducted to ascertain the economic impact of South Africa's largest hunting province, the Limpopo Province.

\section{STUDY AREA}

Ritchie and Goeldner (1994) define the economic impact of tourism as the net economic change in a host community that results from the spending of tourists (in this case, hunters) in a given area. The magnitude of the economic impact of tourism depends on the following: first, the total number of tourists (in this case number of hunters) who visit an area or country; second, the duration of the stay; third, the average spending of the tourists (hunters) in that area or country; and fourth, the circulation of tourism expenditure throughout the area or country (Saayman, 2000). This last is the multiplier effect, which is normally explained in terms of the direct, indirect, and induced effects that expenditure has on the regional economy. The importance of this is that it shows the leakages from the local economy - and the smaller the leakages the greater the economic impact. FIGURE 1 shows a conceptual framework for estimating the total economic impact of hunting.

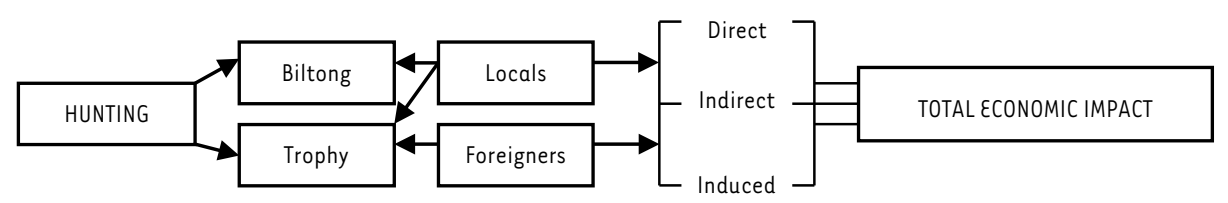

FIGURE 1: Conceptual framework for determining the economic value of hunting

To estimate economic impacts, the "new money" generated for the local economy by tourism is normally considered (Gelan, 2003). Within tourism, tourists visiting a province or region usually create this "new money". This study therefore considered revenue from both foreign and domestic hunters visiting the Limpopo Province from outside the province to represent "new money", and excluded day excursions to the region by local people. Tourism researchers usually count as "new money" only that generated by visitors from outside the area. Hunters' 
expenditure is an important economic driver because it has an impact on various sectors of the economy, especially in predominantly rural provinces such as the Limpopo Province. Saayman et al. (2009) list many ways in which hunting contributes to forward and backward linkages in South Africa, such as developing infrastructure, creating jobs, improving services, and so on. Forward linkages refer to the supply of additional inputs to other 'upstream' sectors, whereas backward linkages refer to the additional inputs required by producers to supply additional output to meet the increased demand (Conningarth Consultants, 2006b).

Economic impact analyses have been carried out in various fields of tourism research, including those as diverse as sport tourism (Gelan, 2003; Daniels, 2007; Solberg \& Preuss, 2007; Saayman and Rossouw, 2008), regional and country economic impacts (Zhou et al., 1997; Frechtling \& Horvath, 1999; Walpole \& Goodwin, 2000; Fayissa et al,. 2008; Lee \& Chang, 2008), the economic impact of events (Van Heerden, 2003; Saayman \& Saayman, 2004; Van der Merwe \& Saayman, 2008; Saayman \& Rossouw, 2010), and, increasingly, wildlife tourism (Nijkamp, 2004; Tisdell \& Wilson, 2004; Getzner et al., 2005). With regard to economic impact studies of hunting tourism, we found the following international examples: Lindsey et al. (2007), the economic and conservation significance of trophy hunting in sub-Saharan Africa; IAFWA (2002), the economic impact of hunting in America; Baldus and Caulwell (2004), the economic impact of hunting tourism in Tanzania; and BBC Research and Consulting (2008), a report for the Colorado Division of Wildlife on the economic impact of hunting, fishing, and wildlife watching in Colorado. The following are some corresponding studies that have been done in South Africa: Van der Merwe and Saayman $(2005,2008)$, Scholtz et al. (2010), and Van der Merwe et al. (2011), all of which covered only the economic impact of biltong hunting and not both trophy and biltong hunting. $A$ study conducted in Namibia by Barnes et al. (2009) on income generated by hunting, both trophy and biltong, found that trophy hunting generates more income than biltong hunting. The only data we could find about the spending or economic impact of trophy hunters in South Africa was that of the Professional Hunters Association of South Africa (PHASA, 2009), and the only study of the economic impact of both trophy and biltong hunting in South Africa was research conducted by Saayman et al. (2011) in the Northern Cape province. To date no studies have been done of the economic impact of hunting in Limpopo, South Africa's most important province for both trophy and biltong hunting. This will assist in obtaining accurate economic data on hunting, assist in building the hunting industry and identify possible areas of concern.

\section{METHOD}

The research method is divided into three categories: surveys, expenditure data, and SAM multiplier analysis.

\subsection{Surveys}

The study used three data sets, consisting of secondary and primary data. The first derived from a South African quantitative survey of biltong hunters (secondary data), conducted via an online interactive questionnaire hosted on "Potshot", the weekly electronic newsletter of the magazine 'SA Hunter' from October 2009 to January 2010. A total of 344 ( $n$ ) completed questionnaires were returned and used in the statistical analysis (Scholtz et al., 2010). The questionnaire consisted of three sections of which only sections $A$ and $B$ were used. Section $A$ collected demographic details (marital status, age, and province of origin), Section $B$ investigated spending behaviour (number of persons paid for, number of times the park has 
been visited, length of stay, and amount spent), and Section $C$ asked for more detailed information about the consumers' general behaviour (asking which magazines and newspapers and hunting techniques they preferred). This paper refers only to the data from Sections A and B. The questionnaire, which had been used in previous similar research, was designed by Saayman et al. (2011).

The second data set came from interviews with game farm owners in Limpopo in May and June 2010 (primary data). This questionnaire was also Saayman et al. (2011). The Wildlife Ranching South Africa (WRSA) database, which has a member basis of 797 ( $N=797)$ product owners, was used for the Limpopo Province. From this database, a probability sample was drawn of 206 respondents $(\mathrm{N}=206)$, who were telephonically interviewed in the evenings between 18:00 and 20:00, when they were likely to be accessible. The third data set, representing trophy hunting participation and expenditures for the 2007-2008 hunting season, was obtained from the Professional Hunters Association of South Africa (PHASA) (secondary data). The data represents all trophy hunters who have hunted in South Africa during the 2007-2008 hunting season (6 841 respondents).

The aforementioned datasets were combined and used collectively in the multiplier analysis (i.e. as the total hunter spend), which is discussed in the following sections.

\subsection{Expenditure data}

We estimated that hunters spent a total of R1.5 billion on licences, travel, supplies, and services directly connected with hunting in Limpopo in 2010. Of the total spending by all hunters (see column 4 in TABLE 1), biltong hunters spent an estimated $94 \%$ of this total and trophy hunters only $6 \%$ (see TABLE 1). Spending on species accounted for $45 \%$ of total expenditure, accommodation and food for $22 \%$, new equipment for $10 \%$, fuel and transport for $9 \%$ and meat processing services for $5 \%$. All other expenditures accounted for approximately $9 \%$ of the total expenditure for 2010. On average, biltong hunters contributed an estimated Rl.4 billion and trophy hunters R88.2 million to the Limpopo economy in 2010. If expressed in 2006 terms, biltong hunters contributed R1.4 billion and trophy hunters R84.4 million.

In comparison, in the Northern Cape hunters spent an estimated R696 million (biltong hunters R661.7 and trophy hunters R34.3 million) in total. Food and accommodation accounted for approximately $16 \%$ of the total expenditure, new equipment $8 \%$, fuel/transportation $8 \%$ and meat processing services $6 \%$. Spending on game/species accounted for $56 \%$. All other expenditure accounted for approximately $8 \%$ of the total expenditure to the Northern Cape economy (Saayman et al., 2011:123). 
TABLE 1: Expenditure directly related to hunting in 2010 (incl. game; ZAR, deflated to 2006 prices)

\begin{tabular}{|c|c|c|c|}
\hline Category & Trophy hunters & Biltong hunters & Total hunters \\
\hline Accommodation & 21645386 & 155306343 & 176951729 \\
\hline Fuel & 0 & 125427463 & 125427463 \\
\hline Food & 9276594 & 81410095 & 90686689 \\
\hline Meat processing & 0 & 66767057 & 66767057 \\
\hline Ammunition & 3092198 & 70850079 & 73942277 \\
\hline Gear & 3092198 & 38882508 & 41974706 \\
\hline Daily fees & 0 & 44777800 & 44777800 \\
\hline Beverages & 0 & 46519579 & 46519579 \\
\hline Butchery facilities & 0 & 32490437 & 32490437 \\
\hline Clothes & 3092198 & 29621887 & 32714085 \\
\hline Toiletries & 618439 & 12594311 & 13212751 \\
\hline Medicine & 618439 & 8555140 & 9173579 \\
\hline Tobacco & 0 & 4358886 & 4358886 \\
\hline Transport & 12368792 & 0 & 12368792 \\
\hline Trophy handling fees & 1855319 & 0 & 1855319 \\
\hline Other & 6184396 & 27656975 & 33841371 \\
\hline Game/Species & 22599789 & 641979812 & 664579601 \\
\hline Total & 84443749 & 1387198373 & 1471642121 \\
\hline
\end{tabular}

Source: Authors' calculations based on PHASA (2008) data and Scholtz et al. (2010)

Because most hunters are accompanied by friends or family members, the total number of visitors to the Limpopo Province would therefore most likely exceed the number of hunters. This additional value-added impact was not, however, covered by this research.

\subsection{Economic impact}

The goal of economic impact analysis is to measure the economic activity attributable to some activity or event. It is typically measured in terms of gross output or production, value added or income, employment, and tax revenues generated by expenditures made as a result of the activity or event.

Economic impact analysis views the economy as a system of interrelated sectors. The system is driven by the demands for final goods and services. Initial expenditures (e.g., by hunters) are generally called the direct costs of an activity and their effects on the economy are direct effects. Purchases by suppliers (e.g., tourist outfitters, hotel and restaurant owners, charter operators) of the final goods, and services of materials and supplies to maintain the original 
purchases are called indirect effects. Induced effects occur when workers in the sectors that benefit from direct and indirect expenditures spend their additional income on consumer goods and services. The direct plus indirect plus induced effects equal the total effect.

Two popular methods to derive the indirect and induced effects are input-output analysis (I-0) and social accounting matrices (SAMs), which deliver multiplier effects (Wagner, 1997). In addition, the use of Computable General Equilibrium (CGE) models has gained ground in recent years, with the studies by Zhou et al. (1997), Dwyer et al. (2004), and Saayman and Rossouw (2010), which has the advantage of modelling additional price effects. Yet the I-0 models and SAMs, together with the multiplier analysis that these generate, remain some of the most popular methods of estimating the economic impact of activities or events. Wagner (1997) notes that the SAM is based on I-0 models, since an I-0 model forms part of the SAM, but the SAM has the advantage of including additional information on income distribution within an economy.

At each step of the spending chain some demand will be directed to goods and services produced outside the immediate economy. Imports of goods and services produced in other provinces and countries are leakages from Limpopo's economy. Likewise, at each step of the spending chain some expenditure is absorbed by indirect taxes. Both imports and indirect taxes will reduce the size of indirect effects. Similarly, leakages in the form of direct taxes and household savings limit the size of the induced effects.

Hunters spend money on a variety of goods and services for trip-related and equipment-related purchases. Trip expenditures include food, accommodation, transport, and other incidental expenses. Equipment expenditures consist of rifles, ammunition, hunting gear, camping equipment, special hunting clothing, and other costs. These direct expenditures are only part of the economic impact of hunting, since they also have ripple effects throughout the economy.

The effect on the economy in excess of direct expenditures is known as the multiplier effect. For example, an individual may purchase ammunition to use while hunting. Part of the purchase price will stay with the local retailer. The local retailer in turn pays a wholesaler who in turn pays the manufacturer of the ammunition. The manufacturer then spends a portion of this income to pay businesses supplying the manufacturer. Each rand of local retail expenditure can affect a variety of businesses.

Thus expenditure associated with hunting can ripple through the economy, affecting economic activity, employment, and household income. To measure these effects, a regional input-output modelling method was used in this study to derive estimates for gross output, value added, employment, and labour income associated with hunting.

The estimates for total industry output, employment, and employment income were calculated using a SAM for the Limpopo Province.

\subsection{SAM multiplier analysis}

The multiplier concept is applied using economy-wide consistent data on a particular (regional/provincial) economy as is normally contained in a SAM, which extends the basic I-0 concept from production to income distribution and includes both social and economic data for a region (Raa \& Sahoo 2005). A SAM consists of data from I-0 tables, national income statistics, and household income and expenditure statistics. Unlike national accounts, 'a SAM attempts to classify various institutions according to their socio-economic backgrounds instead of their economic or functional activities' (Chowdhury \& Kirkpatrick, 1994). In the present study we used 
a SAM for the study area (i.e. the Limpopo Province) which was developed by Conningarth Consultants (2006a). The SAM (based on 2006 prices) used in these analyses distinguishes 46 sectors, 12 household types, and 4 ethnic groups.

In order to transform a SAM into a model suited for economic impact assessment it is necessary to assume that all the relations in the SAM are of linear type and that prices are fixed (at best in the short run). Thus, the SAM can be used directly to simulate the effects of shocks on some exogenous variables or accounts (i.e. expenditure-induced effects by the hunting activity). This type of exercise is known as SAM multiplier analysis (Dumont, 2000).

Various studies on the decomposition of activity multipliers that explain the circular flow of income (Stone, 1981; Pyatt \& Round, 1979; Defourny \& Thorbecke, 1984; Robinson \& RolandHolst, 1988) form the basis of the method applied in this study. A brief explanation of the method-of how specific multipliers were calculated-is provided below (based on the work of Dumont, 2000).

The first step is to define $A_{n}$ as the matrix of average expenditure propensities, which can be obtained by dividing a particular element in any of the endogenous accounts by the total for the column account in which the element occurs. $X_{n}$ represents the exogenous accounts and $Y_{n}$ the total of each endogenous account. Based on these notations it follows that:

$$
\mathrm{y}_{\mathrm{n}}=\mathrm{A}_{\mathrm{n}} \mathrm{Y}_{\mathrm{n}}+\mathrm{x}_{\mathrm{n}}=\left(\mathrm{I}-\mathrm{A}_{\mathrm{n}}\right)^{-1} \mathrm{x}_{\mathrm{n}}=\mathrm{M}_{\mathrm{a}} \mathrm{X}_{\mathrm{n}}
$$

According to Pyatt and Round (1978) the multiplier matrix $\left(M_{a}\right)$ can be decomposed into three economically meaningful additive components: (i) a transfers matrix that picks up the net multiplier effects induced on a given set of accounts by exogenous transfers accruing to the given set; (ii) an open-loop matrix that captures the cross effects between different groups; and (iii) a closed-loop matrix specifying the multiplier effects of an exogenous inflow on an endogenous account and return to the original recipient.

First, one can start with $\hat{A}$ as the diagonal bloc matrix extract from the matrix $\mathrm{A}_{\mathrm{n}}$ :

$$
\widehat{A}=\left[\begin{array}{ccc}
A_{11} & 0 & 0 \\
0 & A_{22} & 0 \\
0 & 0 & A_{33}
\end{array}\right]
$$

From equation 2 it follows that:

$$
\begin{aligned}
& y_{n}=A_{n} Y_{n}+x_{n}=\left(A_{n}-\widehat{A}_{n}\right) y_{n}+\widehat{A}_{n} y_{n}+x_{n} \\
& =\left(I-\widehat{A}_{n}\right)^{-1}\left(A_{n}-\widehat{A}_{n}\right) y_{n}+\left(I-\widehat{A}_{n}\right)^{-1} x_{n} \\
& =A^{*} y_{n}+\left(I-\widehat{A}_{n}\right)^{-1} x_{n}
\end{aligned}
$$

By multiplying both sides of equation 3 by $\mathrm{A}^{*}$ and substituting for $\mathrm{A}^{*} \mathrm{y}_{\mathrm{n}}$ on the left-hand side now gives:

$$
\begin{aligned}
y_{n} & =A^{* 2} y_{n}+\left(I-A^{*}\right)\left(I-\widehat{A}_{n}\right)^{-1} x_{n} \\
& =\left(I-A^{* 2}\right)^{-1}+\left(I-A^{*}\right)\left(I-\widehat{A}_{n}\right)^{-1} x_{n}
\end{aligned}
$$

Likewise, multiplying both sides of the initial equation (3) by $\mathrm{A}^{* 2}$ yields: 


$$
\begin{aligned}
y_{n} & =A^{* 3} y_{n}+\left(I-A^{* 2}\right)\left(I-\widehat{A}_{n}\right)^{-1} x_{n} \\
& =\left(I-A^{* 3}\right)^{-1}+\left(I-A^{*}+A^{* 2}\right)\left(I-\widehat{A}_{n}\right)^{-1} x_{n}
\end{aligned}
$$

Otherwise put:

$$
y_{n}=\left(I-A^{* k}\right)^{-1}+\left(\sum_{j=0}^{k-1} A^{* j}\right)\left(I-\widehat{A}_{n}\right)^{-1} x_{n}
$$

It is also important to note that the three-step decomposition that will be retained reflects the sequence of substitution that corresponds to one complete cycle in the circular flow of income within the economy and thus that it is not an arbitrary choice (Dumont 2000).

If one notes that $M_{a 1}=\left(I-\widehat{A}_{n}\right)^{-1}, M_{a 2}=I+A^{*}+A^{* 2}$ and $M_{a 3}=\left(I-A^{* 3}\right)^{-1}$ it follows that: $\mathrm{M}_{\mathrm{a}}=\mathrm{M}_{\mathrm{a} 1} \mathrm{M}_{\mathrm{a} 2} \mathrm{M}_{\mathrm{a} 3}$.

Finally $\mathrm{M}_{\mathrm{a}}$ can also be re-written as:

$$
\mathrm{M}_{\mathrm{a}}=\underbrace{\mathrm{I}}_{\text {Initial Change }}+\underbrace{\left(\mathrm{M}_{\mathrm{a} 1}-\mathrm{I}\right)}_{\begin{array}{c}
\text { Net contribution of } \\
\text { trasnfer multiplier }
\end{array}}+\underbrace{\left(\mathrm{M}_{\mathrm{a} 2}-\mathrm{I}\right) \mathrm{M}_{\mathrm{a} 1}}_{\begin{array}{c}
\text { Net contribution of } \\
\text { open loop or cross- } \\
\text { multiplier effects }
\end{array}}+\underbrace{\left(\mathrm{M}_{\mathrm{a} 3}-\mathrm{I}\right) \mathrm{M}_{\mathrm{a} 2} \mathrm{M}_{\mathrm{a} 1}}_{\begin{array}{c}
\text { Net contribution of } \\
\text { circular or closed- }
\end{array}}
$$

The following section describes the results obtained through the application of the aforementioned method.

\section{RESULTS AND DISCUSSION}

Using the figures in TABLE 1 and the latest SAM for the Limpopo Province (the SAM was compiled by Conningarth Economists and is available from the Development Bank of Southern Africa $[D B S A])$, the researchers were able to determine the estimated share of expenditure in the study area (using the multiplier concept). In TABLE 1 , the real spending by both groups of hunters (biltong and trophy) on goods and services in the province is presented. The expenditure data by hunters have been deflated to 2006 values, allocated to industry sectors and converted to producers' values to be compatible with the Limpopo SAM. All the results are therefore expressed in 2006 values.

The information included in the SAM enabled the researchers to identify the impacts of hunting on different household groups, different components of the labour force, and income inequality (Blake et al., 2008). The figures in TABLE 1 for spending by hunters, recorded in surveys (biltong and trophy hunters), were used to estimate the share of total expenditure in the study area resulting from hunting (TABLE 1 ). On the basis of these figures, one can expect that the manufacturing and service industries catering directly for hunters will experience the greatest direct economic impact from hunting-related activities. Conversely, the industries that only indirectly supply these activities will receive less benefit (subject also to the backward linkages' in the regional economy). 


\subsection{Secondary and total economic impact}

Biltong and trophy hunters' spending data were converted to the associated increase in production, income and jobs in the region using economic multipliers from a SAM for the Limpopo Province. The SAMs multiplier approach uses distinct multipliers for each expenditurerelated sector. The multipliers convert expenditure into the associated increase in production, jobs and income and estimate secondary effects as spending circulates through the regional economy. To show this for the biltong and trophy hunter spending, one needs to 'correct' the direct impact (e.g., expenditure figures in TABLE 1) by the multiplier effect. These results, based on the 'corrected' spending by the two types of hunters (refer to Column 2 in Tables 2 and 3 ), are contained in the next two sections.

\subsection{Trophy hunters}

The quantification of the direct, indirect, and induced impact of spending by trophy hunters in the region (Limpopo) in 2010 (deflated to 2006 prices) is summarized in TABLE 2. As this expenditure in part comes from trophy hunters from other provinces and abroad buying goods and services in the region, it represents an inflow of money into the region, mobilizing economic activity, and generating employment and additional revenue for the province. 'Production' refers to the total turnover generated by each sector in the regional economy. As such, production comprises two components: demand for intermediate inputs (resources) by an activity (domestically produced and imported goods and services); and the total value-add generated by an activity (Conningarth Consultants, 2006b). TABLE 2 shows the effects on production (using the production multipliers) of expenditure resulting from trophy hunting in 2010 (deflated to 2006 prices).

The trophy hunters' spending was mostly on trade and accommodation. From TABLE 2 it is clear that the largest direct impact was on trade and accommodation (32\%), transport and communication (23\%), manufacturing (13\%), and financial and business services ( $11 \%$ ). Through the 'backward linkages', large indirect and induced impacts were also experienced in the manufacturing sector, reflecting an indirect impact of R4.4 million and an induced impact of R1.9 million. Note that if one ignores the direct effect in the manufacturing sector one finds that $46 \%$ of the total increase in production was as a result of 'backward linkages', with direct expenditure representing $54 \%$. A more detailed (disaggregated) analysis of the various sectors would be useful, but unfortunately the researchers did not have sufficient expenditure data to do this.

Any acquisition of goods and services from non-regional suppliers (leakages) was excluded from the analysis and therefore did not exert a significant direct or indirect effect in the regional economy. By excluding this indirect impact, although small in significance, one was able to present a more accurate estimate of the impact of trophy hunting in the region. 
TABLE 2: Trophy hunters' impact through production multipliers (ZAR, 2006 prices)

\begin{tabular}{|c|c|c|c|c|c|}
\hline Sector & $\begin{array}{l}\text { Direct } \\
\text { impact }^{l}\end{array}$ & $\begin{array}{l}\text { Indirect } \\
\text { impact }^{2}\end{array}$ & $\begin{array}{l}\text { Induced } \\
\text { impact }^{3}\end{array}$ & $\begin{array}{c}\text { Total } \\
\text { impact }^{4}\end{array}$ & $\begin{array}{c}\text { Percentage } \\
\text { (total) }\end{array}$ \\
\hline Agriculture & 5586410 & 2230692 & 1695729 & 9512832 & $9.2 \%$ \\
\hline Mining & 974494 & 280702 & 393288 & 1648484 & $1.6 \%$ \\
\hline Manufacturing & 7438722 & 4412471 & 1940025 & 13791218 & $13.3 \%$ \\
\hline $\begin{array}{l}\text { Electricity \& } \\
\text { water }\end{array}$ & 1559626 & 784766 & 605308 & 2949700 & $2.8 \%$ \\
\hline Construction & 528920 & 328672 & 136354 & 993946 & $1.0 \%$ \\
\hline $\begin{array}{l}\text { Trade \& } \\
\text { accommodation }\end{array}$ & 17699069 & 9673342 & 6036442 & 33408853 & $32.3 \%$ \\
\hline $\begin{array}{l}\text { Transport \& } \\
\text { communication }\end{array}$ & 13763136 & 5766398 & 4409484 & 23939018 & $23.1 \%$ \\
\hline $\begin{array}{l}\text { Financial \& } \\
\text { business } \\
\text { services }\end{array}$ & 6427399 & 2220026 & 2618146 & 11265571 & $10.9 \%$ \\
\hline $\begin{array}{l}\text { Community } \\
\text { services }\end{array}$ & 3683023 & 822893 & 1549930 & 6055847 & $5.8 \%$ \\
\hline Total (in ZAR) & 57660800 & 26519962 & 19384707 & 103565469 & $100.0 \%$ \\
\hline
\end{tabular}

Source: Authors' calculations based on multiplier analysis

1 Initial expenditures (for example, by day visitors) are generally called the direct costs of an activity and their effects on the economy are direct effects.

2 Purchases by suppliers (for example, hotel and restaurant owners, and charter operators) of the final goods, and services of materials and supplies to maintain the original purchases are called indirect effects.

3 Induced effects occur when workers in the sectors stimulated by direct and indirect expenditures spend their additional income on consumer goods and services.

4 The direct plus indirect plus induced effects equal the total effect.

The analysis of the spending by trophy hunters in 2010 (deflated to 2006 prices) allows for two conclusions. The first is that the direct effect represents $56 \%$, the indirect effect $26 \%$, and the induced affect $19 \%$ of the total increase in expenditure. The second is that the activity sectors that benefited most from spending by trophy hunters were trade and accommodation, transport and communication, manufacturing, and financial and business services. The regional spending by trophy hunters in these sectors exceeded R103.6 million, and represented some $9 \%$ of the total spending by all hunters (including biltong hunters) in the region. Research by Saayman et al. (2011) on the economic impact of hunting in the Northern Cape Province showed that the impact of trophy hunting totalled R65 million, which is significantly less than that of the Limpopo Province.

\subsection{Biltong hunters}

To estimate the economic impact of the spending by biltong hunters (meaning non-residents or foreigners as well as those living in Limpopo and the rest of South Africa), the researchers used 
the same approach as for trophy hunters. On the basis of the expenditure figures, it was estimated that the direct impact in the region of the biltong hunters' expenditure amounted to approximately Rl.1 billion, distributed among the nine activity sectors. The sectors that benefited most from spending by biltong hunters were trade and accommodation, agriculture, financial and business services, and manufacturing.

It is important to note that the direct impact of the biltong hunters' expenditure (R611 million) represented more than $91 \%$ of the total expenditure by hunters (R669 million) in Limpopo in 2010. The quantification of the direct, indirect, and induced impact of this expenditure in the region is summarized in TABLE 3. The total impact was Rl.1 billion (TABLE 3). Limpopo biltong hunters spent approximately the same as those in the Northern Cape (Saayman et al., 2011).

TABLE 3 clearly shows that the largest direct impact was on trade and accommodation (29\%), agriculture (21\%), financial and business services (18\%), and manufacturing (16\%). Through the 'backward linkages', large indirect and induced impacts were also experienced in the agricultural sector, reflecting an indirect impact of R53.5 million and an induced impact of R40.6 million. If the direct effect in the agricultural sector is ignored, $42 \%$ of the total increase in production is as a result of 'backward linkages', with direct expenditure also representing $58 \%$ of the total impact. To sum up, it can be concluded that the direct effect represented $57 \%$, the indirect effect $23 \%$, and the induced affect $20 \%$ of the total increase in expenditure.

TABLE 3: Biltong hunters' impact through production multipliers (ZAR, 2006 prices)

\begin{tabular}{|c|c|c|c|c|c|}
\hline Sector & $\begin{array}{l}\text { Direct } \\
\text { impact }\end{array}$ & $\begin{array}{l}\text { Indirect } \\
\text { impact }\end{array}$ & $\begin{array}{l}\text { Induced } \\
\text { impact }\end{array}$ & $\begin{array}{c}\text { Total } \\
\text { impact }\end{array}$ & $\begin{array}{l}\text { Percentage } \\
\text { (total) }\end{array}$ \\
\hline Agriculture & 132203241 & 53503603 & 40551917 & 226258761 & $21.0 \%$ \\
\hline Mining & 9510222 & 2974040 & 3810698 & 16294960 & $1.5 \%$ \\
\hline Manufacturing & 96803252 & 49884310 & 27372868 & 174060430 & $16.2 \%$ \\
\hline $\begin{array}{l}\text { Electricity \& } \\
\text { water }\end{array}$ & 12712128 & 6420320 & 4926177 & 24058625 & $2.2 \%$ \\
\hline Construction & 4564505 & 2836395 & 1176712 & 8577612 & $0.8 \%$ \\
\hline $\begin{array}{l}\text { Trade \& } \\
\text { accommodation }\end{array}$ & 169095864 & 88128240 & 59533195 & 316757299 & $29.4 \%$ \\
\hline $\begin{array}{l}\text { Transport \& } \\
\text { communication }\end{array}$ & 49506488 & 20360653 & 15882533 & 85749674 & $8.0 \%$ \\
\hline $\begin{array}{l}\text { Financial \& } \\
\text { business } \\
\text { services }\end{array}$ & 117489921 & 23179175 & 52129839 & 192798935 & $17.9 \%$ \\
\hline $\begin{array}{l}\text { Community } \\
\text { services }\end{array}$ & 19352209 & 4323838 & 8144010 & 31820057 & $3.0 \%$ \\
\hline Total (in ZAR) & 611237829 & 251610575 & 213527949 & 1076376353 & $100.0 \%$ \\
\hline
\end{tabular}

Source: Authors' calculations based on multiplier analysis 


\subsection{Overall impact}

The analysis described in the two previous sections allowed us to estimate the direct impact on the Limpopo economy of spending by trophy and biltong hunters. However, to evaluate the total impact of the spending by hunters in the province, it was necessary to 'correct' the direct impact by the multiplier effect. Production multipliers were thus used for each of the activity sectors. Multiplying the direct impact in each activity sector for the specific production multipliers gives the total impact of the hunter spending for each of the province's economic sectors (TABLE 4). The sum of the impacts in each of the sectors gives us, in turn, an estimate of the total impact of hunter spending in the province.

TABLE 4: Total impact of hunter spending in the Limpopo Province on regional production (ZAR millions, 2006 prices)

\begin{tabular}{|c|c|c|c|c|c|}
\hline Sectors & $\begin{array}{c}\text { Spending by } \\
\text { biltong } \\
\text { hunters }\end{array}$ & $\begin{array}{c}\text { Spending by } \\
\text { trophy } \\
\text { hunters }\end{array}$ & $\begin{array}{c}\text { Direct impact } \\
\text { of hunters }\end{array}$ & $\begin{array}{l}\text { Production } \\
\text { multipliers }\end{array}$ & Total Impact \\
\hline Agriculture & 132.203 & 5.586 & 137.790 & 1.650 & 235.772 \\
\hline Mining & 9.510 & 0.974 & 10.485 & 1.777 & 17.943 \\
\hline Manufacturing & 96.803 & 7.439 & 104.242 & 1.594 & 187.852 \\
\hline $\begin{array}{l}\text { Electricity \& } \\
\text { water }\end{array}$ & 12.712 & 1.560 & 14.272 & 1.932 & 27.008 \\
\hline Construction & 4.565 & 0.529 & 5.093 & 1.879 & 9.572 \\
\hline $\begin{array}{l}\text { Trade \& } \\
\text { accommodation }\end{array}$ & 169.096 & 17.699 & 186.795 & 1.879 & 350.166 \\
\hline $\begin{array}{l}\text { Transport \& } \\
\text { communication }\end{array}$ & 49.506 & 13.763 & 63.270 & 1.730 & 109.689 \\
\hline $\begin{array}{l}\text { Financial \& } \\
\text { business } \\
\text { services }\end{array}$ & 117.490 & 6.427 & 123.917 & 1.762 & 204.065 \\
\hline $\begin{array}{l}\text { Community } \\
\text { services }\end{array}$ & 19.352 & 3.683 & 23.035 & 1.322 & 37.876 \\
\hline Total & 611.238 & 57.661 & 668.899 & & 1179.942 \\
\hline
\end{tabular}

Source: Authors' calculations based on multiplier analysis

1 Unit is ZAR millions except for the variable 'Production multipliers'

The analysis of the results indicates that the direct economic impact of the two types of hunters' spending in the region (which is in the order of R669 million), produced an additional R511 million of indirect and induced impact, giving a total impact in the region in excess of R1.2 billion for 2010 (deflated to 2006 prices). This is equivalent to an aggregated production multiplier in the order of 1.76 compared to the Northern Cape hunters spent in excess of R300 million (Saayman et al., 2011) more in the Limpopo Province. Therefore, for each rand spent by the two types of hunters in the region, 76 cents were generated additionally in terms of indirect 
expenditure. The aggregated production multiplier is obtained by dividing the total impact by the direct impact.

One of the elements of the additional value-add that results from the hunters' spending in Limpopo is remuneration of employees, which in turn affects household income. The household income multiplier thus measures the magnitude of changes that occur both to household income and to spending and saving patterns. The impact on low-income households is particularly important, as it can be used to indicate how much hunting contributes to poverty alleviation throughout the provincial economy.

Low-income households in the Limpopo SAM receive earnings within the income intervals $R 1-R 6$ 400 (from the 2001 population census), representing about $50 \%$ of the total population in the province. These households receive about $23 \%$ of the income generated through low-skilled labour, $6 \%$ from skilled, and $2 \%$ from high-skilled labour. The rest of households in Limpopo earn between R6 401 and R204 201 or more and receive 11\% of their income through capital invested in enterprises, followed by $10 \%$ from high-skilled labour. Production activities that consistently participate in the paths of income generation for enterprises and households are mining, petroleum, farming, forestry, and business services. Limpopo households therefore have relatively strong links to the mining and industrial sectors, and these sectors hire labour with different set of skills.

Using the same SAM for the Limpopo economy, it was thus possible to estimate the impact of total hunter spending at the level of families' income. To do this one calculates specific household income multipliers for each activity sector and then multiplies these by the values of the total sector's impacts (TABLE 5).

The low multipliers (ranging between 0.02 and 0.08 ) for low-income households in the province reflect a high degree of dependence of these households on government transfers as a source of income. For households in the lower $50 \%$ of the income distribution, government transfers represent a bit less than $33 \%$ of income. Hence, the small shares of factor earnings saved by low income households imply relatively low multipliers for these households.

The aggregated income multiplier, valued at 0.41 , can be interpreted as the increment of the Limpopo family's income for each rand of spending by hunters in the province. It was estimated that a total of R480 million in remuneration in Limpopo would not have been received if there had been no hunting (TABLE 5). 
TABLE 5: Impact of hunter spending in the Limpopo Province families' income (ZAR millions, 2006 prices)

\begin{tabular}{lccccc}
\hline \multicolumn{1}{c}{ Sectors } & $\begin{array}{c}\text { Total } \\
\text { impact } \\
\text { (ZAR } \\
\text { million) }\end{array}$ & $\begin{array}{c}\text { Low-income } \\
\text { households }\end{array}$ & $\begin{array}{c}\text { Rest of the } \\
\text { households }\end{array}$ & $\begin{array}{c}\text { Total } \\
\text { households }\end{array}$ & $\begin{array}{c}\text { Percentage } \\
\text { (total) }\end{array}$ \\
\hline Agriculture & 235.772 & 12.710 & 72.026 & 84.737, & $17.7 \%$ \\
\hline Mining & 17.943 & 1.372 & 7.081 & 8.453, & $1.8 \%$ \\
\hline Manufacturing & 187.852 & 8.589 & 52.848 & 61.436, & $12.8 \%$ \\
\hline Electricity \& water & 27.008 & 1.808 & 10.537 & 12.344, & $2.6 \%$ \\
\hline Construction & 9.572 & 0.416 & 2.496 & 2.912, & $0.6 \%$ \\
\hline $\begin{array}{l}\text { Trade \& } \\
\text { accommodation }\end{array}$ & 350.166 & 19.351 & 125.009 & 144.359 & $30.1 \%$ \\
\hline $\begin{array}{l}\text { Transport \& } \\
\text { communication }\end{array}$ & 109.689 & 5.683 & 35.924 & 41.606 & $8.7 \%$ \\
\hline $\begin{array}{l}\text { Financial \& business } \\
\text { services }\end{array}$ & 204.065 & 13.947 & 91.307 & 105.254 & $21.9 \%$ \\
\hline Community services & 37.876 & 2.081 & 16.889 & 18.970 & $4.0 \%$ \\
\hline $\begin{array}{l}\text { Total } \\
\text { Tom }\end{array}$ & $1,179.942$ & 65.957 & 414.116 & 480.072 & $100.0 \%$ \\
\hline
\end{tabular}

Source: Authors' calculations based on multiplier analysis

As expected, low-income households benefit from stronger ties with low-skilled workers, but they also receive income from enterprises. The skilled labour in low-income households obtained their incremental income primarily from agriculture, and indirectly from financial services used by business services. Income received by low-income households comes from a very diverse set of activities, whereas high-income households received capital rents from a larger set of activities, which is thereafter invested in enterprises.

Labour is a key element of the production process. This indicator measures job creation and reveals how much each sector contributes to creating employment opportunities and, ultimately, to distributing salaries and wages among various types of labourer, which in turn should have a positive impact on the economy of the Limpopo Province (TABLE 6). 
TABLE 6: Impact at the level of employment

\begin{tabular}{lccc}
\hline \multicolumn{1}{c}{ Sectors } & $\begin{array}{c}\text { Total impact } \\
\text { (ZAR million, 2006 prices) }\end{array}$ & Labour multipliers & $\begin{array}{c}\text { Equivalent jobs } \\
\text { (number) }\end{array}$ \\
\hline Agriculture & 235.772 & 14.620 & 3447.0 \\
Mining & 17.943 & 4.037 & 72.4 \\
\hline Manufacturing & 187.852 & 4.692 & 881.4 \\
Electricity \& water & 27.008 & 3.925 & 106.0 \\
\hline Construction & 9.572 & 6.292 & 60.2 \\
\hline Trade \& accommodation & 350.166 & 5.663 & 1982.9 \\
\hline Transport \& communication & 109.689 & 4.038 & 442.9 \\
\hline Financial \& business services & 204.065 & 5.774 & 1178.3 \\
\hline Community services & 37.876 & 5.576 & 211.2 \\
\hline Total & 1179.942 & & $\approx 8382$ \\
\hline
\end{tabular}

Source: Authors' calculations based on multiplier analysis

1 The labour multiplier indicates the number of job opportunities that will be created as a result of changes in production to the value of ZARl million caused by a particular activity)

Finally, using the values presented in TABLE 4, it was also possible to estimate the impact of hunter (biltong and trophy) spending at the level of jobs in Limpopo. On the basis of figures from the Limpopo SAM, and using data on the labour force per province relative to the business volume and jobs per activity sector in South Africa for 2006, it was possible to estimate the impact of hunter spending on the province's job level, as shown in TABLE 6. The table shows that 8382 jobs may depend on hunting, in addition to those of people permanently employed at game farms in the province (4 603). This translates into 95 jobs per $\$ 1$ million tourism (hunters) spending. The World Travel and Tourism Council (2012) indicated that, on average, travel and tourism in the world create 50 jobs per $\$ 1$ million spend, and in the United States it is close 20 jobs per $\$ 1$ million. The reason for the difference might be that employees' average income in South Africa (or Africa) is lower than that of America; therefore more people get employed per $\$ 1$ million hunters spending. Consequently, the absence of hunting would have meant a reduction of 8382 jobs in the province, and a reduction of the number of permanent employees (4 603). The sectors most affected by the absence of hunting would have been agriculture, manufacturing, and trade and accommodation. The jobs listed in TABLE 6 include the direct, indirect, and induced impact in a manner similar to total industrial output and include both full-time and part-time jobs.

\section{MANAGEMENT IMPLICATIONS}

The results of this research suggest the following implications for management. Firstly, it was confirmed that the Limpopo Province contributes the most to hunting and that hunting has an important role to play, which supports the finding by Warren (2011) that the Limpopo Province is South Africa's leading hunting destination. This finding has important management implications 
for the hunting industry in this province. First, the government and private sector need to sustain and support this industry, as, if they neglect it, it will have negative consequences such as loss of income and job creation in the province. Therefore all stakeholders need to work together in marketing the province as a hunting destination and develop hunter-friendly legislation that will benefit hunting and the development of hunting products. Hunter-friendly legislation refers to easy accessible permits for hunting, transportation and location of game. Legislation concerning permits is a provincial matter; therefore it is possible to implement legislation in one province that differs from the others, which is currently the case (Koen, 2014).

Secondly, employment created in the province due to hunting is significantly greater than in other provinces (Saayman et al., 2011); therefore hunting can be seen as a tool to address poverty alleviation. The implication therefore is that the provincial government and private sector should provide game farm owners and employees with training programmes in skills such as tracking, guiding, professional hunters' training, skinning, taxidermy, and housekeeping to increase their skills and thus the quality of game farm products. Currently, skills training is neglected due to a shortage of training programmes and instructors or trainers, and these courses are also very expensive. Game farms are mostly located in rural areas, and this means that staff need to travel long distances for formal training. This also implies that they will be away from work for some time, which adds to the problems facing skills training (Giampicoli et al., 2014).

Thirdly, since biltong hunters spend significantly more than trophy hunters they remain the main hunting market in Limpopo. This supports the finding by Saayman et al. (2011) regarding hunting in the Northern Cape (but contradicts that of Barnes et al. (2009) regarding hunting in Namibia). The implication is that game farm owners should maintain good relations with the biltong hunter market and hunters' organizations. It is also important that product owners provide for the biltong hunters' needs, for example by stocking their game farms with the preferred species and developing hunting packages that are value for money.

Lastly, since hunting contributes to the province's overall tourism growth, for example by infraand suprastructure development, marketing and promotion of the province, and conservation of fauna and flora, it is important to prevent leakages, for example by employing local people rather than outsiders and purchasing supplies locally rather than in neighbouring provinces such as Gauteng. Currently the tendency is that some lodges buy most of their supplies in Gauteng, as the prices are better and the variety greater. This implies that business chambers need to get involved. The sectors that benefit the most from hunting are trade and accommodation, agriculture, transport and communication, manufacturing, and financial and business services.

\section{LIST OF REFERENCES}

Baldus, R. D, \& Cauldwell, A.E. (2004). Tourist hunting and its role in development of wildlife areas in Tanzania. Community Wildlife Management Programme. Dar Es Salaam: GTZ. Jul. 2004.

Barnes, J.I., Nhuleipo, 0., Baker, A.C., Muteyauli, P.I. \& Shigwedha, V. (2009). Wildlife resource accounts for Namibia, 2004. DEA Research Discussion Paper No 79, Windhoek: Directorate of Environmental Affairs, Ministry of Environment and Tourism.

BBC Research and Consulting. (2008). The economic impacts of hunting, fishing and wildlife watching in Colorado. Prepared for Colorado division of wildlife. Colorado: BBC Research and Consulting. 
Blake, A., Arbache, J.S., Sinclair, T.M. \& Teles, V. (2008). Tourism and poverty relief. Annals of Tourism Research, 35(1), pp. 107-127.

Chowdhury, A. \& Kirkpatrick, C. (1994). Development policy and planning: an introduction to models and techniques. Routledge: London.

Conningarth Consultants. (2006a). Disaggregated social accounting matrix for South Africa. Mafikeng: Government Printer,

Conningarth Consultants. (2006b). Economic multipliers for the North West Province. Mafikeng: Government Printer.

Damm, G. R. (2005). Hunting in South Africa facts - risks - opportunities. Africa Indaba 3:1-23.

Damm, G.R. (2004). Kenya's wildlife service at crossroad. Africa Indaba 2:8-9.

Daniels, M. J. (2007). Central place theory and sport tourism impacts. Annals of Tourism Research 34(2), pp. 332-347.

Defourny, J. \& Thorbecke, દ. (1984). Structural path analysis and multiplier decomposition within a social accounting matrix framework. The Economic Journal, 94(373), pp. 111-136.

Dumont, J. (2000). SAM Multiplier Analysis. [Online] Available: http://www.pepnet.org/fileadmin/medias/pdf/FicheMultiplicateur.pdf. (Accessed 16 April 2012).

Dwyer, L., Forsyth, P. \& Spurr, R. (2004). Evaluating tourism's economic effects: new and old approaches. Tourism Management, 25(3), pp. 307-317.

Eloff, T. (2002). The economic realities of the game industry in South Africa. In Africa Game Ranchers Association. Proceedings of the $5^{\text {th }}$ International Wildlife Ranching Symposium, 20-23 March 2001, Pretoria, South Africa.

Fayissa, B., Nsiah, C. \& Tadassa, B. (2008). The impact of tourism on economic growth and development in Africa. Tourism Economics, 14(4), pp. 807-818.

Frechtling, D. C, \& Horvath, $\varepsilon$. (1999). Estimating the multiplier effect of tourism expenditure on a local economy through a regional input-output model. Journal of Travel Research, 37(4), pp. 324-33.

Gelan, A. (2003). Local economic impacts: the British Open. Annals of Tourism Research, 30(2), pp. 406-425.

Getzner, M., Spash, C.L. \& Stagl, S. (2005). Alternative for environmental valuation. Routledge: New york.

Giampicoli, A. Van der Merwe, P. \& Saayman, M. (2014). The impact of private game farms on local community development. SAIMS 2013 Conference proceedings. North-West University. Oxford press.

Higginbottom, K. (2004). Wildlife tourism: an introduction. In K. Higginbottom (ed). Wildlife tourism: impacts and planning. Melbourne: Common Ground Publishing.

International Association of Fish and Wildlife Agencies (IAFWA). (2002). Economic importance of hunting in America. Washington: IAFWA.

Koen, J. (2014). Game farming and the law. . In P. van der Merwe and E. Du Plessis (eds). Game farm and hunting tourism.Stellenbosch: Sun MeDia,

Lee, C.C., \& Chang,C.P. (2008). Tourism development and economic growth: a closer look at panels. Tourism Management, 29(1), pp. 180-192. 
Lindsey, P.A., Roulet, P. \& Romañach, S.S. (2007). Economic and conservation significance of the trophy hunting industry in sub-Sahara Africa. Biological Conservation, 134(4), pp. 455-469.

Nijkamp, P. (2004). Environmental economics and evaluation. Northampton: Edward Elgar Publishing Limited.

PHASA (Professional Hunters Association of South Africa). (2009). Professional Hunters Association of South Africa: Statistics. Pretoria: PHASA.

Pyatt, G. \& Round, J.I. (1979). Accounting and fixed price multiplier in a social accounting matrix. Economic Journal, 89(356), pp. 850-873.

Raa, T. \& Sahoo, A. (2005). Competitive pressure on the Indian household: a general equilibrium approach. Economic Systems Research, 19(1), pp. 57-71.

Ritchie, J R B. \& Goeldner, C. (1994). Travel, tourism, and hospitality research, $2^{\text {nd }}$ edition. London: Wiley.

Robinson, S. \& Roland-Holst, D.W. (1988). Macroeconomic structure and Computable General Equilibrium models. Journal of Policy Modeling, 10(3), pp. 353-375.

Saayman, M. \& Rossouw, R. (2008). The economic value of the 2010 Soccer World Cup. Acta Commercii, 8(1), pp. 1-14.

Saayman, M. \& Rossouw, R. (2010). The Cape Town international jazz festival: more than just jazz. Development South Africa, 27(2), pp. 255-272.

Saayman, M. \& Saayman, A. (2004). The economic impact of cultural events. South African Journal of Economic Management Sciences, 7(4), pp. 629-642.

Saayman, M. (2000). En route with tourism. 2nd edition. Potchefstroom: Institute for Tourism and Leisure Studies.

Saayman, M., Van Der Merwe, P. \& Rossouw, R. (2011). The economic impact of hunting in the Northern Cape Province. South African Journal of Wildlife Research, 41 (1), pp. 120-133.

Saayman, M., Van Der Merwe, P., Rossouw, R. \& Oberholzer, S. (2009). A socio-economic impact study of the Northern Cape hunting industry. Potchefstroom: Institute for Tourism and Leisure Studies.

Samuelsson, $\varepsilon$. \& Stage, J. (2007). The size and distribution of the economic impacts of Namibian hunting tourism. South African Journal of Wildlife Research, 37(1), pp. 41-52.

Scholtz, M., Van der Merwe, P. Saayman, M. (2010). The national profile and economic impact of biltong hunters in South Africa. Potchefstroom : Institute for Tourism and Leisure Studies.

Solberg, H.A. \& Preuss, H. (2007). Major sport events and long-term impacts. Journal of Sport Management, 21(2), pp. 213-234.

Stone, R. (1981). Aspects of Economic and Social Modelling, No. 126. Geneva: Librairie Druz.

Tisdell, C. \& Wilson, C. (2004). Economics of wildlife tourism. In K. Higginbottom (ed.) Wildlife tourism: impacts and planning. Melbourne: Common Ground Publishing.

Van Der Merwe, P. \& Saayman, M. (2004). Managing game farms from a tourism perspective. 2nd edition. Potchefstroom: Ons Drukkers.

Van Der Merwe, P. \& Saayman, M. (2005). National profile and economic impact of biltong hunters in South Africa. Potchefstroom: Institute for Tourism and Leisure Studies. 
Van Der Merwe, P. (2004). Game farms as sustainable ecotourism attractions. Unpublished PhD Thesis. Potchefstroom: North-West University.

Van Der Merwe, P. Saayman, M. (2008). The national profile and economic impact of biltong hunters in South Africa. Potchefstroom: Institute for Tourism and Leisure Studies.

Van Der Merwe, P., Saayman, M. \& Krugell, W.F. (2004). Factors that determine the price of game. Koedoe, 47(2), pp. 105-113.

Van Der Merwe, P., Scholtz, M. \& Saayman, M. (2011). The national profile and economic impact of biltong hunters in South Africa. Potchefstroom: Institute for Tourism and Leisure Studies.

Van Heerden, A. (2003). Economic impact of Aardklop National Arts Festival. Dissertation, Potchefstroom: North-West University.

Van Hoven, W. (2005). Ecotourism and game ranching: why it works. Paper delivered at Ecotourism South Africa Confex, Indaba Hotel, 9-11 November 2005, Johannesburg, South Africa (Unpublished.).

Wagner, J.E. (1997). Estimating the economic impacts of tourism. Anna/s of Tourism Research, 24(3), pp. 591-608.

Walpole, M.J. \& Goodwin, H.J. (2000). Local economic impacts of dragon tourism in Indonesia. Anna/s of Tourism Research, 27(3), pp. 559-576.

Warren, R. (2011). A spending model for biltong hunters. Unpublished PhD Thesis. Potchefstroom: North-West University.

World Travel and Tourism Council. (2012). Benchmarking travel and tourism's economic impact against other sectors. London: World Travel and Tourism Council.

Zhou, D., Yanagida, J.F., Chakravorty, U. \& Leung, P. (1997). Estimating economic impacts from tourism. Annals of Tourism Research 42(1), pp. 76-89. 